\title{
A Conversation with Milton Hatoum
}

\section{Marília Librandi-Rocha}

Stanford University

Translation from Portuguese by

\section{Tom Winterbottom and Melissa Canney}

Acclaimed author Milton Hatoum is originally from a part of the world that has become the center of debates concerning our planetary survival: the Amazon. In this interview-the first extensive interview published in English-he describes how he transforms his experiences of living, traveling, and reading into the written word, and presents a beautiful and specific definition of the reader as a "stationary traveler." Based on questions sent in by e-mail by scholars from all over Brazil and other parts of the world, Hatoum speaks about several of his novels and describes the differences between documentary-based and experimental literary production. He also talks about some of his favorite authors in contemporary fiction, the theme of Latin American patriarchalism as portrayed through some of his characters, and the presence and importance of artists in his books. He recommends some books from the Amazon, and points out the "numbered days" of the Amazon rainforest and the terrible social neglect in the city of Manaus.

The interview was organized by Marília Librandi-Rocha (Stanford University) and Lucia Ricotta (Universidade Estadual do Sudoeste da Bahia), and questions were posed by Stefania Chiarelli (Universidade Federal Fluminense), Luiz Costa Lima (PUC-Rio), John Gledson (University of Liverpool), Marília 
Librandi-Rocha (Stanford University), Mirella Marcia Longo (Universidade Federal da Bahia), and Susana Scramin (Universidade Federal de Santa Catarina). ${ }^{1}$

Stefania Chiarelli: In your work, you compare the idea of reading and traveling with the notion of travel as reading, and your books provide the only permanent home for your characters, contrasting with the geographical, psychological and cultural dislocations that they experience in their fictional existence. According to this perspective, what is the relationship between you, the reader, and your own literary obsessions in the works that make up your repertoire?

Milton Hatoum: Travel and literature are part of my life. When I was very young, I left Manaus to study in Brasília. Having published a book of poetry in 1978, I then lived in many cities in Brazil and Europe while I was trying to become a writer. I also spent a semester as a visiting professor at Berkeley, and one month as a writer-in-residence at both Stanford and Yale. Of course, a writer does not need to travel in order to write fiction. The reader is a stationary traveler and every writer, before publishing anything, should read good books. But travel opens up other worlds and other cultures, and it is an important and recurrent topic in literature. It is one of the central themes of Baudelaire's poetry: the desire to travel is one of the poetic forms of love. To travel is to translate, to interpret, and this is valuable for both cultures: that of the traveler and that of the foreign country. I tried to approach this theme in the story A natureza ri da cultura. Books that I read in my early youth have deeply influenced me: stories by Machado de Assis and Flaubert, and the novel Vidas Secas by Graciliano Ramos. I read those books in Manaus when I was 13 or 14 years old, and to have read Flaubert at that time was a miracle. I began to study French at a very young age because my Lebanese grandmother wanted me to speak French at any cost. I was also forced to readas a punishment from a Portuguese teacher at Pedro II High School in Manausexcerpts of Os Sertões by Euclides da Cunha. I remember one of my uncles bought books from the old Globo publishing house, and I spent the nights reading books in a hammock in the backyard of our house. Later, in 1968 and 1969 at the technical school in Brasília, I first read Sartre, Guimarães Rosa, João Cabral, Carlos 
Drummond de Andrade, Bandeira, and two Greek tragedies by Aeschylus. It was in São Paulo in the 1970s that I became a more disciplined reader. Discipline is relative, of course: the repressive brutality of the dictatorship struck the University of São Paulo. There were not many quiet and disciplined readers who did not get involved with the student movement. I studied architecture at the University of São Paulo and frequently took courses in literary theory and Hispanic Literature. One day we asked David Arrigucci Jr. to give us a list of great books, which served as my compass. It was a selection of classic, indispensable books for anyone who wanted to write. Some authors, like Beckett and Céline, I only read when I lived in Europe. In France, I discovered a work by an author, Marcel Schwob, who I continue reading today, and later I even translated La croisade des enfants into Portuguese. In truth, I was interested in Schwob because Jorge Luis Borges had written the preface to an edition of Vies imaginaires. I don't know which of these authors particularly influenced me. When you really like a book you run the risk of trying to write that same book, but in an inferior way, as the great books are unique. Therefore it is better to find a voice of your own-it might be much more modest but at least it will be yours.

SC: The novels Relato de um certo oriente (1989) and Dois irmãos (2000) associated your name with themes of immigration and cultural dislocation. However, in your other works, the tendency to minimize the presence of immigration is noticeable. Can we therefore speak of an exhaustion of this memorialistic bias concerning the Arab-Amazonian community?

MH: Perhaps it has not been exhausted, because childhood and adolescence are decisive periods for an author. If I were to really milk the past, I think that I could still get two or three pieces of prose out of it. But when an author aged over 50 looks back, he sees that his life at 25 or 30 years of age was a type of late childhood or adolescence. In some stories of $A$ cidade ilhada, there are traces of my experiences from living in Europe during the 1980s, but I still have not written anything about the 1970s when I lived in São Paulo. The experiences of a pervasive and ubiquitous human being at times seem like memories, and memories do not ask to knock on the door of imagination. 
Luiz Costa Lima: Modernism reached the pinnacle of its experimentation with Ulysses and Finnegan's Wake. Going the other way, through lexical and syntactical poverty, the theatrical and romantic Beckett assumes an identical radicalism. Don't you think that, even with the latest cutting-edge novels (like those of Philip Roth and J. M. Coetzee, for example), there is a retreat from those lines of extreme experimentalism? If you agree, how would you explain this retreat? If you disagree, how do you explain the difference between Joyce and Beckett, and the more recent writers?

MH: I agree that there has been a retreat. It is difficult to be sure of the reasons for this, but perhaps I can give two or three basic responses. The first is that modernist literature inhibited its own successors: when I lived in France, my French friends would ask: "How am I supposed to write after Proust, Céline, and Beckett?" I answered them with another question: "How can I write after Guimarães Rosa?” The work of Rosa explores the limits of our language, which is the biggest impasse of the Avant-garde. Authors like Cortázar and Osman Lins innovated with narrative structure and the internal composition of the novels, and they innovated with the style of narration and explorations of certain themes. However, the syntax and lexicon do not present many problems in the reading process. I think that there are many ways to construct a fictional narrative, but to innovate with language without being artificial, without it merely being a stylistic exercise, is what has to be highlighted. Rosa and Joyce are genial writers. Julián Rios, a Spanish writer, wrote Larva, another innovative novel. It's an experimental novel that is very Joycian; indeed, it is an audacious and daring text, astonishingly daring. I remember that in a conversation I had with Haroldo de Campos-in truth almost a monologue, as Haroldo was an eloquent scholar-he was surprised when I told him that I had read Larva. I read that great book by chance: I met Julián at a book fair in Miami, and soon we became close, as if we were both shipwrecked in that book fair of vanity, or of lust. When he found out that I was Brazilian, he began to recite the first page of Grande Sertão by heart. Julián is a Galician, from Vigo. He speaks Portuguese; as a matter of fact he speaks various languages. That is how I came to read Larva, a difficult read, but worth it. Ríos' other novels are less 
experimental but always inventive, always dialoguing with other writers, making a literary genre or a style of humorous narration through parody. Other important novels, such as Porta do Sol by Elias Khoury or Tempo de migrar para o norte by Tayeb Salih, and novels by Sandor Márai, are examples that contemporary narrative is alive. The two latter authors have already died, but their work will continue to be read for a long time.

There is also the pressure of the market, which has grown exponentially over the last three decades. Writers who live off their writing perhaps could be more daring, but they then would run the risk of not being published or of having few readers. Not long ago, the motto at American universities was "publish or perish." Today, the motto of globalization (a euphemism that tries to pass off the shameful exploitation of capital) is: "Sell or perish." Sometimes, even some great novels written in a conventional language do not attract a large public readership. A Brazilian novel of high literary quality, like Lavoura arcaica by Raduan Nassar, has never been translated into English. How to explain this? A few years ago, when Don Delillo was in Brazil, he told me that nowadays, besides writing a book, he also had to publicize it by traveling throughout the United States. Borges, with his habitual irony, wrote in the prologue of El informe de Brodie that "every language is a tradition and every word a shared symbol; it is insignificant that an innovator is able to alter it."

LCL: What do you think that the use of first-hand travel experiences does to your fictional work, bearing in mind the prominence of documentary as a genre-of which regionalism is just one variety?

MH: There are writers who travel in order to write; that is to say: travel is a part of a literary project that is more or less premeditated as a travel narrative or a fictional novel. Bruce Chatwin's books and Mongólia, by Bernardo Carvalho, are good examples as they are not documentary works. In my case, I left Manaus because I had the intuition that intellectual life in the province was closed, limited, and unproductive. This is exactly what a professor tells the character Yakub in Dois irmãos. Later on, I wanted to live far from Brazil, far from the dictatorship that greatly affected my generation. These displacements did not have a 
literary objective, and only years later did they serve as material for some novels and short stories. If documentary ostensibly appears in a fictional narrative, the fiction loses its aesthetic quality, as novels should not be explanatory. Documenting and research are less interesting than the moral and social conflicts of the characters, and much less so than the internal coherence of a narrative. On an extreme level, they are of no interest whatsoever to the experienced reader. I think that the big challenge facing the novelist is to transform his experience of life and reading into language. Events and episodes from the past, individual experience, and historical dimensions are merely pretext for future stories. Experience only acquires depth when language transcends the facts.

John Gledson: You have translated Flaubert, amongst others, into Portuguese. For you, what is the relationship, if any, between translating and writing fiction?

MH: Ever since romanticism, the great poets and authors were also translators. In À la recherche, Proust wrote that "the obligation and work of a writer are also those of a translator." Everything is translation: a novelist translates his experience into language, a translator reflects on that experience and constructs a parallel text, but this parallelism contains a paradox as there is a vanishing point where the two texts must converge. In a notable essay on translation, Antoine Berman critiques French translations that seek to relay simply the meaning of the original, and so limit themselves to literal translations to make the translation clearer. To this end, they "clean" the awkward sections, and change the rhythm, alliterations, and style of the original. It is a beautified translation, written in classic French, and well mannered. Berman critiques this sort of translation that he calls "ethnocentric", and insists that a translation should be "experience and reflection, subjective and objective of personal knowledge." As such, writing and translation are similar jobs. A translated text is an image that reflects itself on the other side of the mirror, but this image also reflects the essence of the original work.

JG: What is the role of serious, erudite fiction (unsatisfactory adjectives, but even so...) in a world that is increasingly dominated by other means of communication. Would you like to see filmed adaptations of your work? 
MH: I still think that good literature resists time and technological innovations. Crime and Punishment and The Dubliners will be read for the next twenty or fifty years, even if that is as an e-book. That said, I cannot read more than ten pages on a computer screen as I suffer from chronic photophobia. I am sure that there are millions of readers with various degrees of photophobia. As a result, I write with a pen, and perhaps it is because of this that the passage from manuscript to computer takes so long, as I am doing now. Concerning the adaptation of novels for movies, there are numerous proposals: the director Marcelo Gomes would like to film Relato de um certo oriente; Luis Fernando Carvalho wants to adapt Dois irmãos for four-part television series. I am not sure what the current status of that project is. And I just recently found out that he wants to adapt Órfãos do Eldorado for the big screen. I like the work of these two directors. If they make these adaptations, I know that they will not be "commercial" films. That's the way it should be, too, as I have never written nor do I intend to write commercial novels.

Marília Librandi-Rocha: In your work there is a sensory abundance of smells, colors, and flavors that make the world of Manaus present for the reader, above and beyond the plots and characters. Which texts and films (or other materials) do you consider crucial for an intelligent understanding of Amazônia-works that make it present from a distance?

MH: The critic and philosopher Benedito Nunes published a list that consists of the fundamental history, fiction, and poetry books about the Amazon, many of them unknown. I would also mention Max Martins' poetic work, again almost unknown, if not totally unknown. There are many accounts from travelers, naturalists, and missionaries, from João Daniel to Alfred Wallace, and also Euclides da Cunha’s essays from the book $\grave{A}$ margem da História (1909). There are also foreign accounts and novels, like La Casa Verde by Vargas Llosa, and Ecuador by Henri Michaux. I also really like the film "Iracema, uma transa amazônica" by Jorge Bodanzky and the documentary "Um cineasta da selva" by Aurélio Michiles.

MLR: In the $19^{\text {th }}$ century, the work of Sousândrade (from the state of Maranhão) contrasted the indigenous universe of the forest with the universe of New York 
City and the world of the stock exchange. In O Guesa, the forest and the city are interconnected and mutually alter one another, which has consequences on the formal configuration of the poem (such as the verses that are written using newspaper headlines announcing, for example, Tatuturema's dance). How do you see, as a Brazilian citizen born in Manaus and as a novelist, the connection between the forest and the city today, in light of the fact that Amazonia is becoming the center of the contemporary questions of global survival?

MH: This relationship is historical: it makes up part of the process of colonization. Manaus and Belém were founded in the $17^{\text {th }}$ century, when the Portuguese were disputing the possession of the region with Spanish colonizers. They were fortress towns, like many other nuclei of the maritime coast and of the Amazonian interior. Today, they are metropolises with two million inhabitants, and Manaus has become the center for the electronics industry in South America. The two cities depend on the river, through which thousands of people and merchants circulate. The forest's days are numbered: in spite of the pressure of environmentalists and many sectors of society, the dominant power is the might and greed of agribusiness. There are soybean fields and pastures in cleared areas. It is development at any price, not much different from the economic miracle period during the dictatorship. Nature has been banned from Manaus. I am not talking about an idyllic vision, a sort of retour à la nature, but rather about the fact that our cities have been destroyed through real estate speculation. You see this in all Brazilian cities, and in Manaus it is the most serious. It is an equatorial city without vegetation and without shadow. All the streams are polluted. When the environmentalists protest against deforestation, I agree with them, but what I revolt against more is the extreme poverty afflicting thousands of families in Manaus and Belém. If you focus only on the forest or the environment, you can lose sight of the size of the human catastrophe, a critical vision of social inequality.

Mirella Marcia Longo: In Cinzas do Norte, the story is accompanied by descriptions of the plastic forms created by Mundo: designs, the sequence of the "Corpos Caídos," the project of the "Campo de Cruzes" and, above all, "Os 
Sete Quadros: Memórias de um Filho Querido." Found in the middle of realist writing, such descriptions seem to indicate another way of representing a life. Could you say a little about the sources that helped you see these plastic forms projected onto the mind of your reader? Also, could you speak about the role that these descriptions acquire when thought about in contrast to the retrieval of the facts undertaken by Lavo?

MH: "Corpos Caídos," “Campo de Cruzes," and "Memórias de um filho querido" were potential titles for the novel, and when the title Cinzas do Norte arose the three previous options remained as titles for Mundo's artistic work, related to the destiny of the character and with the visual memories of the (ironically, "dear") son. The references came from life and from art. I really admire the work of Francis Bacon and the way he expresses the horror and sadness of human beings in his painting, a horror that he, Bacon, witnessed during World War II. I have read numerous interviews that he gave to English and French reporters. I have a friend from São Paulo that lived in London for about ten years and who knew Bacon; they often went to the same pub, etc. Another friend from the Amazon-also an artist-was arrested and tortured in Rio in 1974. Later he was committed to a psychiatric hospital. He survived, exiled himself to Germany, where he lived for a long time. These two friends were important when I began to think about constructing Mundo as a character. The descriptions of the designs, of the installation ("Campo de Cruzes"), and the seven squares express the character's language, in its various modalities: caricature, painting, design, and urban intervention. Some things (or many things) that Mundo (or Lavo) cannot say through the written word are insinuated through the images. The seven squares of the "Memórias" make up a visual synthesis of the life of that "dear" son. That which cannot be read can eventually be "seen." A reader told me that the caricatures and the series of designs of "Corpos Caídos" are ways to sublimate the humiliation that Mundo suffers during his youth. I don't know about that, because with that you are already reading with interpretation. But there are other veiled references. Another reader perceived features of the Lebanese Artist (of Palestinian origins) Mona Hatoum in the character of Mona, an exile in London. I know and admire the work of that artist, but I was 
not thinking of her. Ultimately, the unconscious makes its incursions without people knowing.

MML: Cinzas do Norte and Órfãos do Eldorado both see the presence of authoritarian parents. Even though these works contemplate the ambivalence of the feelings that those parents arouse in their children and, as such, these feelings increase in complexity, the two novels do not explicitly berate the decadence of the patriarchs whose powers are in decline but still alive through memory and, in the case of Cinzas, projected onto institutions. However, something different seems to happen in "O Adeus do Comandante," a story in A Cidade Ilhada. At the center of the story told by the grandfather-whose plot evokes the account that Francesca tells Dante in Inferno-there is the power of passion, but there is also the potency of a father capable of bequeathing to his children an honor washed in blood. If the storyteller triumphs over the allure of the gray screen on the day that they all waited for the first television signal, his triumph is due to the leader of the family: he is the protagonist of the potent and passionate world whose departure is felt like a loss in the story. Could you talk about that ambivalence in relation to the patriarchal world, and also about the ambivalent feelings concerning paternal figures? They seem to be important as their intimate side is often revealed in your work.

MH: As you noted, the father's attitude in the story is very different from the paternal figure in the novels. In "Adeus ao comandante" it is the honor and the moral hurt that matter. There is treason in the family sphere, which is the moral legacy that the father leaves for his children. In the two novels mentioned, the father figure could easily symbolize the old Brazilian and Latin American patriarchy. The authoritarian madness, the tyranny of the father, is that which we can find in political figures, in bureaucrats, in the arrogant rich, in the police, in the journalists who want to exercise power, and in men who beat their wives... However, these figures can be ambivalent, as you pointed out. Or, rather, they can exercise allure in certain people. The figure of Getúlio Vargas is emblematic like many other dictators, populists, and fascists. There are these ambiguities or ambivalences that should be explored in characters, in these paternal, authoritarian figures. In Cinzas do Norte, just think about Jano's attitude and feelings in relation to Alicia. After 
reading Órfãos, Raduan Nassar told me that Amando Cordovil is not so monstruous... Maybe it is because of the child, or how the child sees his father; but not for other characters, not for the reader.

Susana Scramin: With the exception of Orfãos do Eldorado, in your novels there is always a character that has the soul of an artist who never quite fully develops this artistic being. With Dorner, in Relato de um certo oriente, it is to be a photographer; in Dois irmãos it is French teacher Antenor Laval's admiration of French symbolist poets and defense of liberty; whilst Mundo in Cinzas do Norte is the strongest and most impacting character in your novels, and he does engage with art-strictly opposing Arana. Could you comment a little on your engagement with the discussion of art in your fictional texts?

MH: In Órfãos do Eldorado there is the character Estiliano, a reader of poetry and translator of Kaváfis, whose poem "The City" is an epigraph of the novel and reappears at the end of the narrative when Estiliano translates the second part of the poem, which is also the translation of Amando's destiny. The artists, some of who-like Mundo-are upset, have a role in the fiction because they are characters that are intimate and familiar to me. In Relato, I wanted a foreign photographer to take a critical look at family and society in Manaus. It is different from the look of a tourist, who is just a consumer of novelties or a cultivator of ephemeral pleasures.

SS: Could you comment on the relationship between prose and poetry in your book Dois irmãos with regard to the character Antenor Laval?

MH: I admire novels that lean toward poetic prose, or that soften the frontiers between prose and poetry, like Juan Goytisolo's narratives, and many passages in the works of Proust, Guimarães Rosa, or Virginia Woolf, as well as the last part of Ulysses by Joyce. I think that this relationship between prose and poetry is more noticeable in Relato de um certo oriente, a fictional text moved by memory. It is a narrative with little dialogue and few scenes, and as such the narrator's voice can freely discuss the past, sometimes getting close 
to what David Arrigucci Jr. called "strange poetry." Dois irmãos, being a novel with more dialogue between characters, did not allow this type of narrative in which memorialistic prose can be lyrical. Even so, I tried to speak of poetry and being poetic, not just in the figure of Laval but also in that of Abbas, a character who wrote gazais, a loving distich that is very common in Arabic poetry and whose splendor is based in al-Andaluz culture. Abbas' gazais (and the wine) are decisive in Halim's conquest of Zana in the scene in Biblos restaurant. Laval is an unpublished poet and French teacher who is barbarically assassinated by the police of the dictatorship. I wanted to unite love and death in the figure of two provincial poets: one an Arab and the other a Francophile Brazilian. I think that both have something of me in them, as I used to have Arabic poems recited to me by my father and French poems recited by the good old teachers from my province. A little like in the story "Dois poetas da Província” from the book A Cidade Ilhada, in which a writer enters the labyrinth of language bearing the burden of an entire life, and the only way to find an exit-if that is what they find-is to transform something of this life into fiction.

Note

1 The interview was published in Portuguese in Floema. Caderno de Teoria e História Literária 6 (2010): 19-30.

Marília Librandi-Rocha is Assistant Professor of Brazilian Literature and Culture at Stanford University. She is the author of MaranhãoManhattan. Ensaios de Literatura Brasileira (2009). Her current book project, Writing by Ear, is devoted to understand the presence of the sense of audition in written texts, especially in the fiction of Clarice Lispector and João Guimarães Rosa. 